\title{
Mange slags nordmenn
}

\author{
Det er ikke noe lite tema doktor Manthey «i ledige timer» beskjeftiget seg med - intet mindre enn «mennesket \\ fra dets første fremtreden og nedover i forhistorisk tid». Og selv om han støttet seg på fagfolk av mange slag, \\ blant andre de store arkeologene A.W. Brøgger og H. Shetelig, er det tidstypisk nok ikke arkeologien, men divi- \\ sjonslege Bryn han helst henviser til når han på slutten av artikkelen i Tidsskriftet nr. 4/1932 er kommet frem \\ til Skandinavia. Kort nevnes funn av «lappisk art» før «fundene fra Møre tyder derimot på forbindelser sydfra, \\ og det er derfor sannsynlig, at de er de eldste efterladenskaper fra den kortskallede og mørkhårede men- \\ neskerase, som A. M. Hansen og Bryn mener har befolket Norges kyst før den nordiske rase innvandret \\ og som ennu idag setter sitt preg på folket mange steder langs kysten av vårt land». Artikkelen avsluttes \\ med en hyllest til Darwin (Tidsskr Nor Lægeforen 1932; 52: 201 -25).
}

\section{Det forhistoriske menneske.}

Foredrag ved Vestfold lægeforenings møte 25. oktober 1931. Av Carl Manthey, Horten.

Den vesentligste del av de mennesker, som efter ca. 6000 år f. Kr. innvandret til Norge, har vel imidlertid tilhørt de n nordis ke $\mathrm{r}$ a s e, som kom til å tilhøre hovedmassen av landets befolkning.

Den nordiske rase er doliko-mesocefal med en cefalisk indeks på ca. 78, den har blå øine, lyst hår og forholdsvis stor legemshøide, for voksne menn ca. $175 \mathrm{~cm}$. Det er den samme rase som utgjør hovedmengden av Sveriges folk. I Norge finnes rasen i sin reneste form i Sør-Trøndelag og i Opland; men overalt er den mindre eller mere blandet med et mørkhåret og kortskallet element, som gjør sig sterkest gjeldende i Vest-Norge og i det nordligste Norge. Som gjennemsnittstall fra de senere års antropologiske målinger finner man følgende middeltall for det hele land : cefalisk indeks 79, legemshøide (voksne menn) $172,4 \mathrm{~cm}$. Av de unders $\varnothing \mathrm{kte}$ utgjør de dolikocefale 18,5 pct., mesocefale 56 pct. og brachycefale 25,5 , pct. Blå øine finnes hos henved 64 pct., melerte hos vel 34 pct. og brune hos henved 2 pct. Blond (gul) hårfarve hos ca. 50 pct., lysebrunt hår hos ca. 32 . pct., mørkebrunt hos henved 17 pct. og rødt hår hos vel 1 pct.

På grunnlag av sine undersøkelser rundt om i landet hevder Bryn at den nordiske rase optrer i 2 varieteter : det nordlige slag har mørkeblå øine, lyst gult hår, stor legemshøide og en cefalisk indeks, som visstnok er litt større enn hos det sydlige slag, som har lyseblå øine, askeblondt hår og litt mindre legemshøide. Disse 2 varieteter gjenfinnes også i Sverige og fordelingen av slagene sees av dette kort - lysbillede 28. Nu er det Bryns mening, at denne fordeling av rasen i Norge - Sverige peker hen på 2 forskjellige innvandringsveier, og han finner støtte for denne opfatning i den skandinaviske isbres form under den siste avsmeltningstid. Ca. 7000 år f. Kr. antar man at breen har sett således ut - lysbillede 29. I Jämtland hadde isen da demmet op en stor innlandssjø, som ved de tider brøt igjennem breen østover og delte den i en sydlig og en nordlig del, og mellom disse deler blev der da efterhånden en farbar vei for innvandringen til Trøndelagen, Møre og Helgeland østenfra. Denne gren av den nordiske rase antar Bryn er kommet inn i Sverige fra Finnland - enten over Ålandsøene eller rundt Den botniske bukt. Den annen gren må være kommet fra syd i landet ved den sydøstlige del av Østersjøen over Danmark inn i Syd-Sverige, og en del av denne folkestrøm har så funnet vei langs Sveriges vestkyst inn i Norges sydlige del omkring Oslofjorden og har derfra bredt sig vestover langs kysten og senere opover i dalene.

$\mathrm{N}$ å $\mathrm{r}$ den nordiske rase innvandret til Norge vet man ikke sikkert. Bryn mener at den fordeling av det mørke og det blonde folkeelement, som vi i våre dager finner i Vestlandets skjærgård, fjorder og fjordbunner taler for at den nordiske rase er kommet til Vestlandet kort tid efter breenes forsvinnen fra vestlandsdalenes ytre del, det vil si ca. 5 à 4 tusen år f. Kr., og til Østlandet og Trøndelagen er vel de nordiske folkestammer kommet noget tidligere. I den førromerske jernalder synes der å ha vært en stillstand i innvandringen ; derimot har den skutt fart igjen i den romerske jernaldertid og enn mer i folkevandringstiden. Brøgger antar at våre store dalfører som Hallingdal, Valdres og Gudbrandsdalen først er blitt ordentlig befolket $\mathrm{i}$ det 3 dje til det 5 te århundre e. Kr., idet store skoger og mangel på gode arbeidsredskaper ( $\varnothing \mathrm{kser}$ ) har hindret en utbredt og fast bosetning i det indre av landet før denne tid.

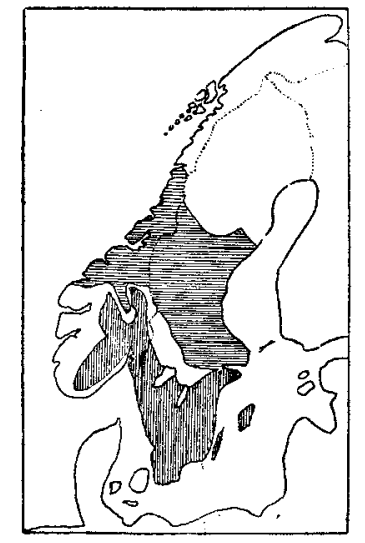

Fig. 28. Det vannrett skrafferte felt: Utbredningsområde for det nordlige slag av den nordiske rase i Norge og Sverige. Det loddrett skrafferte felt: Utbredningsområde for det sydlige slag av den nordiske rase i Norge og Sverige.

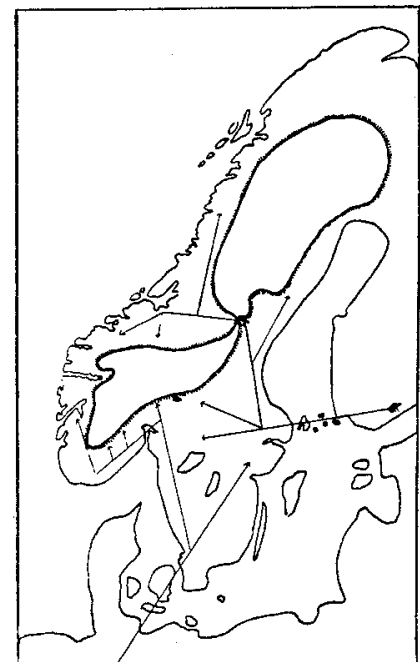

Fig. 29. Den skandinaviske storbres form ea. 7000 år f. $\mathrm{Kr}$. og innvandringsveiene for den nordiske rase. 